\title{
Missing the Third Wave: Islam, Institutions, and Democracy in the Middle East
}

\author{
Ellen Lust
}

Published online: 12 April 2011

(C) The Author(s) 2011. This article is published with open access at Springerlink.com

\begin{abstract}
This article explores why some societies witnessed less political liberalization during the Third Wave of democratization than others, and importantly, the conditions under which opposition forces may refrain from pressing for political reform. Focusing on the Muslim world, it also presents a more complete understanding of when and how political Islam hinders democratization. Specifically, historical experiences with Islamists in the 1970s and institutional structures established by the 1980 s created a condition of uncertainty that enabled some incumbents to thwart liberalization during the Third Wave. Incumbents exploited the fear of political Islam, convincing many secularist opponents that they were better off with the current regime than with Islamist rule. The extent to which incumbents could succeed varied, depending on whether or not Islamist movements had been allowed to mobilize openly and the extent that the regime based its legitimacy on Islam. The argument extends beyond the Muslim world. What is fundamentally at stake is not whether Islam exists as a mobilizing ideology, but whether democratically-minded opponents believe that nondemocratic opposition groups exist that would potentially subvert a democratic opening.
\end{abstract}

Keywords Islam $\cdot$ Democracy $\cdot$ MENA $\cdot$ Democratization $\cdot$ Authoritarianism

Thirty years after the beginning of the Third Wave, Arab states in the Middle East and North Africa (MENA) remained extraordinarily resistant to democracy. ${ }^{1}$ Algeria, Egypt, Jordan, Kuwait, Morocco, Tunisia, and Turkey, and much later, Bahrain and Saudi Arabia, all announced major reforms intended to strengthen popular participation in governance. Egypt led the way, beginning reforms in 1973 and

\footnotetext{
${ }^{1}$ Other states in the MENA fared somewhat better, but they also have had very different historical experiences. Turkey and Iran were the seats of former empires, and Israel was formed as a settler state in the twentieth century.

E. Lust $(\bowtie)$

Yale University, New Haven, CT, USA

e-mail: ellen.lust@yale.edu
} 
renewing its commitment to reform in the 1980s, following President Anwar Sadat's assassination. King Hassan II in Morocco also turned to liberalization after narrowly avoiding his demise in the early 1970s. Political parties were rehabilitated and municipal and parliamentary elections were held in 1976 and 1977, respectively. Similarly, Algeria, Jordan, Tunisia, and Turkey revitalized their party systems and parliaments in the 1980s, and Kuwait renewed its experiment with liberalization after the 1991 Gulf War. In short, the Arab world — like the rest of the world — saw its share of national pacts, political parties, civil society organizations, elections, and other attributes of liberalization, and its potential for democratization. Yet, despite a plethora of agreements signed, parliaments opened, and otherwise outward signs of liberalization, no state made significant, unretracted steps toward freedoms (as measured by the Freedom House Survey) during the Third Wave. Not until January 2011 did citizens across the region take to the streets in a long, sustained attempt to change their regimes, reminiscent of the events in Eastern Europe and Sub-Saharan Africa in the late 1980s and 1990s. Why did it take so long?

Indeed until the dramatic events that unfolded in 2011, reforms had been so minimal that many scholars had abandoned an attempt to analyze the prospects for, or failure of, change, and instead focused on the politics of authoritarianism (e.g., Lust-Okar and Zerhouni 2008; Schlumberger 2007; Albrecht 2010). Emma Murphy noted in 2008 (Murphy 2008: 459), "It is a rather sad indictment of Arab politics today that the word democratization has virtually disappeared from research-based literature on the Middle East." In the absence of change-and even apparent prospects for transitions - scholars focused on the politics of authoritarianism that existed in the region in lieu of the studies of the potential for democratization.

After the uprisings that began in Tunisia, scholars immediately started returning to the questions of transition and potential democratization; yet, fully abandoning the search to solve the puzzle of why reforms were more limited in the region than elsewhere - and to understand variation in the extent of reforms that did take placewould be regrettable for four reasons. First, reforms were more extensive and significant in some Arab countries than others, and it is important to understand the reasons for and the implications of widely diverging experiences (Ottaway and Choucair-Vizoso 2008). Second, Middle East or Arab "exceptionalism" is well established (Stepan and Robertson 2003), but the underlying mechanisms that sustained authoritarianism in the region during the Third Wave are not (Bellin 2004; Pripstein Posusney 2005). Explanations ranging from the cultural and socioeconomic prerequisites of democratization to those based on factors shaping democratizing forces in the region ultimately fall short of explaining the resilience of authoritarian elites or of illuminating the reasons for the important variations in the levels of civil and political liberties extended in the region. Third, understanding the underlying causes of resistance to change can help illuminate why widespread mobilization and the possibilities of change became possible 30 years later. Finally, re-examining the extent of reform in the Middle East provides important lessons for other regions as well. In particular, it demonstrates how the combined forces of institutional structures and regional historical experiences allow incumbents to manipulate their oppositions' beliefs. This contributes to the literature on transitions, determining when incumbents can promote divisions between moderates and radicals (Lust-Okar 2005). 
This article argues that the fear of political Islam, combined with institutional structures that shaped the secularist-Islamist divide, explains both the obstacles to democratization during the Third Wave and the variations in civil and political liberties that exist across it. Specifically, events in the 1970s demonstrated the potential for Islamists to renege on agreements with secularist democrats. This created a condition of uncertainty, wherein secularist opponents questioned Islamists' strength and their intentions. Incumbents, attempting to promote divisions between secularist and Islamist opponents, would raise the specter of the Islamist threat, suggesting to secularist opponents that they were better off with the "devil they knew" than the one they did not (i.e., the regime rather than Islamists). Such threats were particularly effective where Islamists had been excluded from the political arena and thus were a relatively unknown entity. This widened the gap between secularists and Islamists, weakening opponents and making it difficult for them to push for democratic reforms. In contrast, where Islamist forces appeared weak from the outset, or where their inclusion in the political arena had led to more trust between Islamist and secularist opposition, both secularist and Islamist opponents were willing to push for greater reform. Often, they succeeded.

Importantly, the argument made here goes beyond the existence of the "Islamist threat" in the MENA. What is fundamentally at stake is not whether or not Islam is a strong political force, but whether or not democratically-minded opponents believe that there is a high probability that opposition groups exist that would potentially subvert a democratic opening. In predominantly Muslim societies after the 1980s, radical Islamists provoked the greatest fear that opponents may renege on a democratic bargain. However, the important feature was not that these were religiously-based movements, but rather that they represented an opposition group potentially uncommitted to maintaining a democratic bargain, whether or not they won the initial contest. This commitment problem has existed elsewhere-most notably with the communists in post-WWII Europe. ${ }^{2}$ In short, historical experiences and institutional structures, or rules that shaped the relationships between opposition groups, incumbents, and Islam, combined in the MENA to create conditions that were not conducive to liberalization, but the basic structure of politics in the region was not exceptional.

This article begins by reviewing why current explanations do not fully explain the Arab world's resistance to democratization. It then examines the important role that institutions - the structures of contestation governing opposition groups and the extent to which the regime bases its legitimacy in Islam-play in determining the prospects for democratization. Finally, it tests the argument on states with majority Muslim societies. In this way, it differs from the analyses of Islam and democracy that examine states with both predominantly Muslim and non-Muslim populations (e.g., Ross 2001; Fish 2002). Such analyses benefit from more cases and greater degrees of statistical freedom; however, they cannot provide a more fine-grained and nuanced analysis of how the institutions that structured the relationships between opposition groups, as well as these groups and the state, help explain variations in the degree of political liberalization experienced in these states.

\footnotetext{
${ }^{2}$ See also Kalyvas (2000) for a discussion of religious parties and commitment problems in Algeria and Belgium.
} 


\section{The Limits of Predominant Explanations}

Existing explanations do not fully explain the persistence of authoritarianism in the MENA. More detailed overviews of this literature exist elsewhere (Bellin 2004; Remmer 1995; Brumberg and Diamond 2003; Pripstein Posusney 2005), so here I only briefly review how conventional theories of democratization address the puzzle of the Arab world. These fall broadly into two categories: those that focus on preconditions for democracy and those that focus on contingency-based explanations.

Preconditions of Democracy Scholars have long suggested that social, economic, and cultural preconditions make democratization more likely. Presumably, the existence of any single unfavorable factor, and certainly the accumulation of several unfavorable factors, makes the initiation and the consolidation of democracy unlikely. Yet these factors do not explain "Arab exceptionalism," or variation in liberalization that took place across the region.

Economic Conditions Perhaps the most compelling explanation for the persistence of authoritarianism in the region is that oil - and mineral wealth more generallymakes democracy less likely (Crystal 1990; Chaudhry 1997; Beblawi and Luciani 1987; Vandewalle 1998). Michael Ross, (2001) tested this argument most systematically, finding empirical evidence that a negative relationship between oil wealth and democracy holds not only in the MENA, but in other regions as well. Similar arguments, centered on asset mobility, would expect that incumbent elites would be particularly resistant to democratization (Acemoglu and Robinson 2006; Boix and Stokes 2003).

However, Ross also found that when oil, Islam, and a dummy variable for the ME are included in the same analysis of democratization, the dummy variable for the $\mathrm{ME}$ remains highly significant. ${ }^{3}$ In contrast, using a more nuanced analysis of rents, Michael Herb (2005b) argues that oil rents do not "hinder democracy." The presence of oil does not fully explain the persistence of MENA authoritarianism. Furthermore, oil rents do not account for the persistence of authoritarianism in the oil-poor states in the MENA. Many of the non-rentier states are as wealthy as, or wealthier than, states in Sub-Saharan Africa and parts of Asia which saw much more significant liberalization.

Other arguments focus on the level of economic growth and development. From classical modernization arguments (Lipset 1959) to more recent reformulations (Przeworski et al 2000) and rebuttals (Boix and Stokes 2003), scholars argue that the level of economic development and the rate of growth should influence the prospects for political reform. These factors should affect both the ability of citizens to make demands and their desire to do so; and yet, while they may be important, they are not fully satisfactory. Indeed, many MENA countries fare much better than their African counterparts, many of which saw significant political reforms in the last two decades.

\footnotetext{
${ }^{3}$ Indeed, Islam is not statistically significant, and the dummy variable for Mideast is nearly twice the size of the dummy variable for Sub-Saharan Africa (Table 4, p. 345).
} 
Civil Society/Public Opinion Other scholars have suggested that the lack of "democratic socialization" accounts for the failure of democratization in the MENA. Some have focused on weak associational life of civil society, drawing largely from the arguments of Tocqueville and much more recently Robert Putnam. According to this argument, independent, voluntary associations would help foster democratic attitudes and teach self-governance. Consequently, a dearth of voluntary associations and the presence of a strong clan and tribal and kinship ties could help explain the persistence of authoritarianism.

However, this argument is weak on several grounds. A large amount of work on the region, most notably a project by Augustus Richard Norton (1995 and 1996), has documented civil society in many MENA states. Moreover, civil society organizations are not a new phenomenon in the region. For instance, Saad Eddin Ibrahim and his co-authors (unpublished paper) show that by 1952, Egypt counted more than 800 civil society organizations, including eight political parties, 43 labor and professional unions, and seven chambers of commerce. While the structure of civic organizations can be debated - whether they are independent from government and external forces and how they mobilize their support bases - it nevertheless appears that there are "enough" associations to foster democratic attitudes. Recent work on both the MENA and other regions found that associations in non-democratic settings foster the same attitudes toward democratic governance and social capital that they do in democracies (Jamal 2002, 2007; Bermeo 2000; Levi 1996; Tarrow 1996). It is not the absence of associations that leads to non-democratic governance, but rather the lack of democratic governance that leads to the failure of citizens to develop attitudes and trust necessary for democratic participation.

Indeed, the attitudes of average citizens toward democracy in the MENA do not appear to be as different from the other regions of the world as once believed. Survey research in Asia, Latin America, the Middle East, and Sub-Saharan Africa allows us to gauge attitudes toward democracy, although the construction of the surveys is slightly different, producing some problems with comparability. Surveys conducted in a number of MENA countries consistently find that the vast majorityas many as 80-90\% - of the citizens favor democracy (Tessler 2002, 2010; Tessler and Jamal 2008). This figure is similar to, and indeed in many cases higher than, the level of support for democracy found in other regions (e.g., Africa, Latin America) where democracy has taken hold. Presumably, where democratization is highly valued, there should be significant pressure for liberalization as well.

Cultural Context: Islam Another widely accepted explanation for the lack of democracy in the MENA is the presence of Islam. Most notably, Samuel Huntington argued that Islam was "not hospitable" to democracy. For Huntington, both the "consummatory character" of the doctrine and the organization of Islam would thwart democracy. He writes, "In Islam, for instance, no distinction exists between religion and politics or between the spiritual and the secular, and political participation was historically an alien concept" (1984: 208).

This explanation is problematic for several reasons. The argument assumes that Muslims see themselves, first and foremost, as Muslim; in other words, identifications with ethnic groups, regions, economic classes, etc. pale in comparison to Muslim religious identity. It also assumes that there is a single, monolithic 
interpretation of Islam. Yet, there exist various strains of Islam, and it is far from the given that "political participation was historically an alien concept." In both historical and contemporary contexts, there are strong debates over the role of political participation. ${ }^{4}$ The first Caliph Abu Bakr reportedly told the people in the seventh century A.D. that they had the power to remove him if he failed to act according to God's laws, ${ }^{5}$ which is strikingly democratic. Today, as well, Islamic parties take an active role in democratic governance (e.g., Malaysia, Indonesia, and Turkey).

More importantly, there is no strong evidence that the extent to which Muslims see themselves as religious explains the lack of liberties found in the MENA. There is evidence that predominantly Muslim countries are less democratic than non-Muslim countries (Fish 2002), but Stepan and Robertson (2003) effectively argue that there is an "Arab" rather than a "Muslim" democracy gap. Moreover, after examining results from a recent World Values Survey in Egypt, Jordan, Morocco, and Algeria, Mark Tessler $(2002,2010)$ finds little relationship between individuals' levels of religiosity and their attitudes toward democracy. He concludes (2002, p. 19), "[t]here is little evidence, at least at the individual level of analysis, to support the claims of those who assert that Islam and democracy are incompatible."

Regime Type Some scholars also suggest that regime types may affect the likelihood of political reform and democratization. The institutional arrangements help not only determine "who rules," but also how desperately incumbents need to hold on to power and their ability to do so (Geddes 2000). There is some debate over the extent to which it is the institutional arrangements of regimes (Geddes 2000; Hadenius and Toerell 2007; Gandhi and Przeworski 2006), their ruling coalitions (Herb 1999; 2005b), or the strength of dominant parties (Brownlee 2007) that helps to determine the resilience of authoritarian regimes. In any case, however, this explanation is not fully satisfactory. The MENA contains a disproportionate number of the world's twenty-first century monarchies, but regimes in the region are otherwise not significantly different than those which experienced democratization during the Third Wave.

Strategic Concerns A final structural explanation for the exceptionalism of the MENA focuses on international strategic concerns, and particularly the presence of Israel. Some argue that the protracted Arab-Israeli conflict gave authoritarian leaders an excuse to build a large military apparatus, maintain martial law, and repress the people. Perhaps more commonly heard, particularly within the region, is the argument that the combination of oil (as mentioned previously) and Israel in the region has made it profitable for the USA and other Western powers to exert

\footnotetext{
${ }^{4}$ For a similar critique, see Hefner (2000: 7-10).

${ }^{5}$ In his inaugural address, Abu Bakr is reported to have said, "Now, it is beyond doubt that I have been elected your Amir, although I am not better than you. Help me, if I am in the right; set me right if I am in the wrong. Truth is a trust; falsehood is a treason. The weak among you will be strong with me till, God willing, his rights have been vindicated; and the strong among you shall be weak with me till, if the Lord wills, I have taken what is due from him. Obey me as long as I obey Allah and His Prophet, when I disobey Him and His Prophet, then obey me not. And now rise for prayers; may God have mercy on you." (Witness-Pioneer, "Successor to the Holy Prophet," http://www.wponline.org/vil/Articles/companion/ 07 abu_bakr.htm. Accessed July 25, 2003.)
} 
continued influence over "authoritarian puppets." Rather colorfully, Fadlallah illustrates this line of thinking:

In our opinion, the forces of International Arrogance, with the U.S. (represented by the Central Intelligence Agency and its sister organizations) at the helm, have pressed Arab rulers into service as watchdogs for their policies and interests in the Islamic world. Consequently, Muslims are repressed by other Muslims. The Egyptians are being beaten by the Egyptian regime, and the Algerians are beaten by the Algerian regime, so the United States does not have to dirty its hands. ("Islamic Unity" 1995: 62)

The argument that the USA and the West, more broadly, have been deeply invested in maintaining authoritarian leaders in the region is not fully ruled out in this paper nor is a variant on this argument, that citizens support authoritarian regimes because they fear that an alternative, Islamist regime would lose US support and endanger state security (Jamal, manuscript in preparation). Israel and oil are clearly two important strategic concerns for the USA, and ones that - as the Gulf War of 1991 demonstrated - it is willing to defend militarily. The USA has also been willing to defend anti-democratic actions (most notably, the military coup in Algeria) because it fears the emergence of radical, Islamist voices. Ambassador Edward Djerejian (1995: 1), who served as the Assistant Secretary of State for Mideast Affairs in the early 1990s, argued that the USA should promote "the principle of one person, one vote. However, [it should] not support one person, one vote, one time."

Yet, there are good reasons to be skeptical that the USA is fully responsible for the demise of democracy in the region. Indeed, events in the MENA demonstrate that the USA cannot control domestic policy completely. The failure to support the Shah of Iran and to maintain a quiescent alliance with Saddam Hussein suggests that the USA does not fully determine the region's politics. More recently, the January 25th revolution in Egypt and subsequent events across the MENA demonstrated the USA cannot assure its allies' stability. In short, while the USA may not actively promote democratization in the MENA (despite statements to the contrary), it is not single-handedly responsible for the stalled liberalization in the region. Moreover, USA intervention does not explain the variation that does exist in the degrees of liberalization that the region has seen.

It is also not clear that the militarization and propaganda accompanying the prolonged Arab-Israeli conflict has made it possible for incumbent regimes to maintain repressive policies. Incumbents have used the conflict to legitimize their regimes and justify strong militaries and emergency rule. However, their people are not always - or perhaps even not usually - convinced by this rhetoric. Furthermore, there is no clear relationship between the states that are most affected by and involved in the conflict and whether or not the state has initiated liberalization. For instance, although the frontline state of Syria did not announce major liberalization in the 1990s, that of Jordan did. Similarly, it is difficult to see how the Arab-Israeli conflict helps to explain the stalled liberalization in states that are geographically and politically distant from the conflict. Yet, North African states of Algeria, Morocco, Tunisia, and Libya saw as limited change in their civil and political liberties as did the states in the Levant and the Gulf. 
Contingency Theories of Democratization More recent work on the Third Wave of democratization eschewed much of the prerequisite approach. Work in this tradition (e.g., O'Donnell et al. 1987; Linz and Stepan 1996) argues that splits within the ruling elite help to determine the existence and form of political transitions. The relationships between radicals and moderates in the opposition have also helped to determine whether or not transitions occurred and the likelihood of democratic consolidation. Scholars also argue that the relationship between moderate and radical opposition forces at the early stages of liberalization helps to determine the likelihood that democratization succeeds. Where radical forces are too strong, the reform may be stalled (Haggard and Kaufman 1995; Hamladj 2002). These formulations are useful, but they do a poor job of determining when splits will occur, both among opposition and incumbent forces.

However, this literature draws our attention to the importance of leadership. Juan Linz (1990: 162) argues:

Leaders must convince people of the value of newly gained freedoms, of security from arbitrary power, and of the possibility to change governments peacefully, and at the same time they must convey to them the impossibility of overcoming in the short-run the dismal legacy of some non-democratic rulers and accumulated mistakes that have led or contributed to their present crisis.

Leaders are also critical in mobilizing their supporters. Much of social movement theory, which emerged in conjunction with the literature on the third wave, focuses on the importance of opposition leaders in creating networks, mobilizing resources, and framing their movement's concerns (e.g., McAdam et al. 1996; Tarrow 1998; Schwedler 2000; Wiktorowicz 2004). Leaders are important. Yet, as we shall see, leaders need not only be capable of mobilizing supporters, but also motivated to do so.

Social movement theory also points to the role that institutions, or political opportunity structures, play in mobilization. Incumbents create and maintain rules that influence opposition groups' perceptions of the likelihood that they can succeed. This broad insight is important, but the perceptions that opposition groups have of each other and their willingness to join in coalitions and challenge the state also influence the likelihood of mobilization. This provides a useful starting point for us to understand why liberalization in the Arab world has been so frequently reversed and why citizens in some states enjoy more civil and political liberties than those in others.

Yet, these works tend to overlook two important factors. First, they understate the role that state elites play in exacerbating and manipulating the splits between opposition groups. State elites influence the perceptions that opposition groups have of each other and their willingness to join in coalitions, challenging the state (Lust-Okar 2004, 2005). Their ability to do so depends in part, however, on two factors: first, historical legacies that they can call upon to invoke threats, making alternative threats appear not only unpalatable but also credible; and second, the institutional structures, or rules, which have influenced the relationships between incumbents and various opposition elites. These shape both the incentives and uncertainty of opposition leaders, influencing both their ability and willingness to press for reform. 


\section{Islam, Institutions, and Pressure for Reform}

In order to determine the extent of liberalization, and the prospects for democratization, we must understand the circumstances that allow opposition groups to mobilize successfully against the regime. Authoritarian elites choose to grant greater political and civil freedom only under duress, with sustained pressures from opposition spurred by economic crises, foreign policy failures, or other crises. In the MENA, such pressures have existed-with nearly half of the countries experiencing some change in civil and political liberties over the past two decades. Yet, the pressures were not sustained in the MENA as they were elsewhere during the Third Wave-liberalization was reversed, and democracy remained elusive. I turn to the historical context of the threat of political Islam and the ways that institutions affected the oppositions' perceptions of each other for explanations.

Although we will concentrate primarily on the role of the secularist-Islamist cleavage dividing political oppositions, these are not the only social divisions that suppress opposition coalitions. As Brumberg and Diamond (2003: xiii) noted, "autocracies have tolerated, sustained, and even abetted religious, tribal, ethnic and ideological cleavages rather than resolve them democratically." Fostering such subnational identities can be a double-edged sword, helping to stabilize regimes in the short-run by dividing potential opposition coalitions, but making any transition more difficult in the long run (Lust-Okar, 2007). Fostering such cleavages may contribute to stagnation, but it is not unique to the Arab world, and surely does not alone explain the region's remarkable resilience during the Third Wave.

More helpful to understanding Arab exceptionalism is the significance of political Islam in the context of post-cold war democratization efforts. After the fall of the USSR and the decline of communism, democracy appeared the only game in town for much of the world. Citizens could disagree over the speed of economic reforms or the distribution of resources, but in the early years after the wall came down, it seemed that communism, and any other alternative to democracy, was dead. In the predominantly Muslim world, however, possibilities looked different. Various strands of political Islam had been on the rise since the 1970s and only gained strength with the decline of communism. Societies were increasingly divided between those who advocated that Islam plays a major role in politics (e.g., Islamists) and those who preferred a separation between religion and state (e.g., secularists). Indeed, polling data for the early periods is unavailable, but by the 2000s, the Arab barometer found that while the vast majority of the people in Algeria, Jordan, Kuwait, Morocco, Palestine, and Yemen supported democracy, they were divided over the issue of political Islam (Tessler 2010). This dichotomy evoked major questions about what efforts at democratization might bring.

Democracy promoters - both at home and abroad - viewed political Islam as the great new threat to democracy. In reality, of course, the views and aspirations of Islamists are as varied as are those of secularists, and it is no more correct to assume that Islamists necessarily eschew democracy than it is to assume that secularist opponents are always die-hard democrats. However, events of the 1970s, and most notably, the rise of the Islamist theocracy in Iran, led many to fear the potential antidemocratic nature of political Islam, often going so far as to see political Islam as antithetical to democratization. 
Fearing that authoritarian Islamist regimes would only step in to replace existing, secularist-oriented authoritarian regimes, ${ }^{6}$ pro-democratic international and domestic actors often backed away from their demands for political reform. This was most obvious in Algeria in 1991, when the USA, along with the others in the international community and in the Algerian secularist opposition supported the military coup. Democratic elections were overturned which had (up to that point) returned a majority of seats for the Islamic Salvation Front (FIS). Algeria's aborted elections, and the bloody civil war that followed, shook the region.

Indeed, the fear that Islamist movements may perniciously undermine democratization efforts appeared particularly strong in the MENA region, a claim which is largely consistent with Stepan and Robertson's (2003) finding of an "Arab" rather than a Muslim "democracy gap." Even before the aborted democratic experiment and bloody civil war in Algeria, the region witnessed several failed attempts of secularists and Islamists joining together to promote reform: secularists who had joined Islamists in overthrowing the Shah of Iran had found themselves repressed by the subsequent theocratic regime; an initial secularist-Islamist challenge to the Syrian regime had turned into a short-lived but deadly civil war between Islamists and the state; and in Egypt, Anwar Sadat's releasing Islamists from prisons allowed them to gain strength but did not gain their loyalty, eventually contributing to his assassination. Such experiences resonated strongly with others in the MENA - many of whom see themselves as sharing a more common history and culture than they do with Muslims in Africa and Asia. Islam (like any religion) is understood and practiced differently across the Muslim world, in part due to historical differences in the timing and nature of its spread, as well as to the differences in indigenous cultural practices and beliefs present at that time. Of course, Islam in the MENA is also not entirely homogenous, a fact that was highlighted by debates over whether experiences in Shi'a-dominated Iran provided relevant lessons to other predominantly Sunni MENA societies. Yet, those within the MENA arguably saw their understanding of Islam as similar to others within the region, while Muslims in Asia and Africa could more easily dismiss the relevance of these historical experiences.

The fear of Islamists undermined pressures for democratization. Incumbent elites exploited these fears, arguing to domestic and international audiences that the choices were the status quo or an Islamist regime. Secularist, democratic opposition elites also began to talk about the need for a slow process of reform. In general, they recognized their weakness relative to Islamist movements and feared that a rush to elections would bring Islamists to power, who would overturn the democratic process. If they lost at the polls today, many reasoned, they would not have an opportunity to win tomorrow. The risk of a hijacked reform process was simply too threatening to push for change.

\footnotetext{
${ }^{6}$ The extent to which these regimes are aptly described as "secularist" is debatable and became even more questionable as the regimes sought to counter Islamist opposition by establishing their own religious legitimacy. Thus, even avowedly secularist and socialist regimes as those in Egypt and Syria have increasingly used religious rhetoric and promoted conservative Islamic leaders who seek social, although not political, change.
} 
Institutions Structuring Perceptions of Islam

The extent to which such fears existed and dampened opposition pressures for reform varied, however, in part as a result of different institutional structures - that is, specific laws and norms that governed the relationships between the state, opposition, and Islam. As discussed above, not all states with predominantly Muslim societies resisted democratization; and even within the Arab world, there were differences in the extent to which opposition groups mobilized and authoritarian elites expanded political and civil liberties. Where secularist-oriented opposition feared Islamists less, they were willing to join in coalitions against incumbents and demand liberalization. Institutions structured the relationship between political Islam and the regime - and consequently between secularist and Islamist opposition groups as well as these groups and the state. This, in turn, affected opponents' interest in joining together to demand reform.

Incumbent elites took different approaches to the relationship between Islam and the state. They did so in two important ways: first, determining the extent to which the regime's legitimacy would be tied to a special relationship between the state elites and Islam (e.g., secularist or Islamic legitimacy); and second, choosing to include or exclude Islamist groups that are at least relatively independent from state control (e.g., Islamist inclusion or exclusion). There were thus four strategies: a secularist-based state allowing non-state Islamist groups to participate, an Islamicbased state allowing such Islamist participation, an Islamic-based state excluding participation of non-state Islamist groups, and a secularist-based state excluding Islamist participation. As shown in Table 1, this typology extends to all states with predominantly Muslim societies, both in the MENA and elsewhere. The strategies

Table 1 State strategies toward political Islam in 1980

\begin{tabular}{llll}
\hline & Islamist Inclusion & Islamist Exclusion & \\
\hline Secular Regime & Bangladesh & Afghanistan & Libya \\
& Chad & Albania & Mali \\
Indonesia & Algeria & Mauritania \\
Malaysia & Brunei & Niger \\
& Turkey & Burkina Faso & Senegal \\
& & Egypt & Sierra Leone \\
& & Ethiopia & Somalia \\
& Gambia & Syria \\
& Guinea & Tunisia \\
& Iraq & \\
& Jordan & Bahrain & Oman \\
& Kuwait & Comoros & Qjibouti \\
& Sudan & Morocco & Saudi Arabia \\
& & & UAE \\
\hline
\end{tabular}


implemented in the MENA were not significantly different than those implemented elsewhere.

The first set of regimes includes those in which elites claim Islam as a basis for the regime and exclude all other Islamist groups from political competition. Such was the case in Saudi Arabia, for instance, where the king was the "leader, the imam of the Saudi-Wahabi community of believers and subordinate only to the Holy Law, the shari'a" (Kostiner et al. 2000: 131). The family sought to strengthen its position through close relations with the ulama, but it did not provide independent political roles for the ulama, or other Islamist organizations. Similar relations existed in other Gulf States and in Morocco.

The second set of regimes includes those which base their legitimacy on secular socialism and exclude Islamist forces. Revolutionary, dominant party regimes, such as the Ba'thist regimes in Syria and Iraq, the socialist FLN in Algeria and the NeoDestour in Tunisia, took this approach. Ruling elites sometimes attempted to demonstrate Islamist credentials: President Sadat overtly turned toward the Muslim Brotherhood in the 1970s, proclaiming himself the "Believer President"; and even Presidents Asad and Hussein attempted to shore up support through public demonstrations of religious practices. However, in contrast to inclusive regimes, Islam was not a major source of regime legitimacy, and the competing Islamist forces were not permitted in the formal political sphere.

In the third set, which Daniel Brumberg has called "dissonant regimes," the ruling elites base part of the regime's legitimacy upon Islam while at the same time maintaining space for competing, Islamist forces. In Jordan, for instance, King Hussein based his legitimacy, in part, on descent from the prophet but allowed the Muslim Brotherhood to remain an open "charitable society" and granted them cabinet positions in the period of 1957-1989, in part to counter leftist opposition. In Kuwait, too, an informal alliance sanctioned by the regime had existed between Shi'a, tribal members, and the Islamic fundamentalists against leftist and liberal forces. The level of cooperation began to crumble after the 1970 s, as the Islamists had less to offer ruling elites in the face of a declining left and increasingly apparent Islamist threat. Nevertheless, the regimes continued to tolerate the groups.

Finally, in the fourth set, regimes do not base their legitimacy on Islam but do allow Islamist groups to mobilize independently. Turkey provides a case in point. The military coup in 1980 banned the National Salvation Party, as it did all parties at the time. However, the military remained friendly toward Islamist groups and saw them as a way to counter the Kurdish problem, hoping that religious-based solidarities could undermine ethnic loyalties. The military's enthusiasm toward Islamist parties waned as Islamists became stronger in the mid-1990s, but Islamists were not excluded from the system.

This study does not claim to explain the different choices taken in the early 1980 s, but it is important to note that state strategies do not appear to be determined either by the nature of Islamist forces or the level of liberalization. It was not simply the presence of stronger or more radical Islamist forces that explains whether or not incumbents exclude Islamist parties. Morocco, for instance, excluded Islamists which were considered to be relatively weak and moderate. The inclusion of Islamist forces also does not simply reflect already high levels of civil and political liberties. 
Indeed, Jordan was highly repressive in the 1980s, but it permitted the Muslim Brotherhood to play an active role in the formal political sphere.

Rather, there seem to be other explanations for the ways in which state elites structure the relationship between Islam and politics. First, monarchies were more likely to base their legitimacy on Islam than revolutionary regimes were. The extent to which Islam could be fully incorporated into the system varied, however. Morocco and Saudi Arabia, both of which had longer histories of rule, may have found it easier to claim exclusive rights over political Islam than did Jordan and Kuwait, which were created through a more recent state-formation process driven to a large extent by external forces (i.e., "artificially"). Revolutionary, dominant party states, in contrast, were based on socialist frameworks. The majority of these regimes emerged during the 1950s and 1960s with ideological and sometimes financial support from the Soviet bloc. Thus, although these states could not fully ignore the importance of Islam, as the 1973 constitutional riots in Syria demonstrated, they nevertheless emphasized secular legitimacy and, even when they permitted other parties to operate, excluded Islamist forces.

\section{Perceptions of the "Islamic Threat" and Mobilization}

Within the predominantly Muslim world, the fear of Islamists varied. Particularly in the MENA, the prior experiences of failed alliances between secularist and Islamist opponents in Egypt, Iran, and Syria demonstrated the potential force of political Islam. The extent to which secularists feared Islamist movements coming to power also depended in part on institutional arrangements that shaped the relationship between the state and religion.

Whether or not regimes based their legitimacy, at least in part, on Islam affected the extent to which secularists pressed for reform. As Herb (2005a) argues, the more Islamist the incumbent regime, the less secularist opponents felt threatened by the possibility of change. Such regimes did not stand as a bastion against Islamists - a claim that secularist regimes could and did make, but rather they instituted some of the same policies that Islamists advocated. For example, the Saudi regime's strict restrictions on dress and behavior were equivalent to the reforms that many feared Islamists would implement. This was true even though radical Islamist opposition argued that the incumbents were insufficiently dedicated to Islam. Secularists in such regimes were more likely to believe that they had little to lose if Islamists came to power, and thus, they were more likely to demand reform.

In contrast, socialist, secularist regimes could act as a buffer between Islamist forces and secularist opponents. In Tunisia, for instance, the regime could credibly claim to allow secularists more freedoms than a (potentially Islamist) successor would allow. Such was not the case in more conservative states where Islam was incorporated into the basis of the regime's legitimacy. All else equal, secularists in regimes which base their legitimacy on Islam were more likely to demand reform.

Whether or not Islamist forces had been allowed to participate openly in the political sphere also affected the extent to which secularists feared the rise of political Islam, and thus, muted their demand for reform. Such fears were considerably stronger where independent Islamist forces had been excluded from participation than where they had not. 
Excluding Islamists had several implications. First, it increased uncertainty over Islamists' strength. Where Islamists were illegal, it was impossible to determine the opposition's strength through membership rolls, participation at rallies, or other public events. It was also impossible to rely upon estimates or understanding of their strength nearly a decade earlier in estimating their current strength. Thus, political Islam seemed a viable challenge, but the extent of its support was unclear. When Islamists were finally allowed to mobilize, it was difficult to disentangle support for Islamists from support for opposition. This was demonstrated in the Algerian provincial and municipal elections in June 1990, when a large percentage of support for Islamist parties (in this case the FIS) came from those who opposed the system but did not necessarily support the Islamists' goals (Stone 1997: 167).

Second, excluding Islamists strengthened the appearance of militant Islamist radicalism. Islamists, as with adherents of other movements, often become more radical through repression. Exclusion from the system and the failure to gain political concessions through legal means strengthen a radical flank that attacks even its own moderates. Thus, for instance, exclusion of the Muslim Brotherhood in Egypt promoted a radical flank that held similar preferences but believed that moderate means were futile (Ibrahim 1982:10; Ayubi 1980; Kotob 1995). Moderates, with their wings clipped by the regime, found it hard to counter the radicals.

Third, excluded radicals frequently use violent methods to signal their strength. Even where such militants are in fact few, and where they have little real popular support, they can appear to be an enormous threat. This helps to explain why Egyptians saw Islamic activism as "an unprecedented internal threat to society, the regime, and the modern state," (Ibrahim 1988) when public opinion polls found that the vast majority of Egyptians did not support the violence (al-Ahram 1995).

Finally, the exclusion of Islamists in the MENA created a great deal of uncertainty about their "true intentions." In many movements, leaders use contradictory rhetoric: that with which they engage to mobilize their hard-line supporters, and that with which they engage potential political allies; that which is intended to incite, and that which is intended to negotiate. Where the level of knowledge between different oppositions is high, elites can shrug off strident claims, understanding that they have a very specific political purpose. Where the level of knowledge is low, however, the use of rhetoric to mobilize hard-line supporters is seen as representing the "true" intentions of Islamist movements. Although there was some "backdoor" communication between Islamists and secularist opposition forces even where Islamists were formally excluded from the political system, two questions remained: to what extent were Islamists committed to their professed respect for democracy? And, to what extent were the moderate Islamists, with whom they communicated, representative of the dominant, and strongest, Islamist forces?

The fear that Islamists would not commit to democracy was evident in the debate surrounding the FIS' potential victory in Algeria during 1991. FLN reformers and the secularist opposition were clearly aware of the catch-22 which they faced: if they permitted the FIS to win the elections, the FIS may use the victory to mount a theocratic revolution; but if they aborted the electoral process, they would drive a stake through the very democratic process they were trying to promote (Volpi 2003: 52-53). Because secularist democrats did not understand the exact intentions of the Islamists, and under the circumstances, weighted radical statements more heavily 
than moderate ones, many supported aborting the process. The bloody civil war that followed reverberated across the region, escalating the apparent threat of political Islam.

The uncertainty over Islamists' intentions also led to disagreements within, and the weakening of, both sets of opposition forces. Secularist opponents often vehemently disagreed with each other about the potential value of cooperating with Islamist forces, as well as the extent to which they threatened to destabilize the system. Some argued for inclusion of Islamist forces on the basis that they would only become moderate if they were allowed to participate in the system (Abdalla 1993: 29). Others argued against their inclusion, tacitly supporting the government's repression (Karawan 2001). Similarly, although perhaps to a lesser extent, Islamists were divided between those who sought to cooperate with secularists, seeking inclusion into the system, and those who rejected this strategy.

In short, where democratically-minded opposition elites fear that undemocratic opponents exist and were capable of subverting democratic openings, they became unwilling to demand reform. In the MENA, historical experiences and institutional structures allowed authoritarian elites to exploit the uncertainty caused by these factors and led secularist opposition elites to limit their demands for political reform.

\section{Authoritarian Options}

Authoritarian elites in the MENA thus had a powerful tool to use in preserving their regime: the threat of political Islam. The incumbents took advantage of historical legacies, contrasting the threat of a radical Islamic regime against the security of the status quo. They did so outright - referring most frequently to the Iranian revolution and then, later, to the Algerian experience. They also did so by casting doubt on the more moderate Islamist forces. The debate in Egypt is illustrative. The regime accused the Muslim Brotherhood of funding terrorism and acting as the moderate cover of the militant Islamists. The Brotherhood denied this, and secularists split over whether to side with the regime or the Brotherhood. ${ }^{7}$ International forces also exacerbated these trends, supporting the authoritarian regimes in the face of the Islamist threat. They made no secret of their fear that radical Islamists would destroy hopes of democracy and stability, particularly in the MENA. ${ }^{8}$

These dynamics weakened opposition forces in much of the MENA. Islamists were often forced to operate on the fringes of the system. They were relatively strong in the 1990s, but the repression inhibited their ability to demand political reform. Secularists' fears of political Islam often led them to accept the status quo. This was particularly true after the Algerian crisis of 1991 and during the ensuing civil war. As one Moroccan intellectual explained in 1995, "We look to Algeria and Iran and know that we are much better off" (interview, 1995). In Tunisia, where Ben Ali maintained Islamists' exclusion even after moves toward liberalization in 1989, the threat of Islamists pushed trade union leaders as well as the middle classes toward an

\footnotetext{
${ }^{7}$ On these charges and denials, see Ayubi (Ayubi 1991: 73); Abdalla (1993: 30); Interview with Ma'mun al-Hudaybi in FBIS-NES-95-005, January 9, 1995: 22-23; Mustafa Mashhur, in FBIS NES 992-245, 21 December 1992: 19-20; and Hamid Abu al-Nar with al-Sha'b in FBIS, June 24-28, 1994: 21.

${ }^{8}$ This, of course, had a significant impact on US response toward Algeria. See Voll (1997) and Volpi (2003: 53-54).
} 
acceptance of the state's repressive policies (Bellin 2004; 2002 117-119). An Algerian secularist argued similarly in regards to the 1992 Algerian coup, "when faced by a choice between FIS's Ali Belhadj and General Khaled Nezzar, I chose the general" (Brumberg 2002b: 111).

The threat of Islam was much weaker where regimes had previously allowed independent Islamist participation. Such was the case in Jordan, where the regime had provided space for the Muslim Brotherhood as a way to stabilize the political sphere. The fear between Islamists and secularists was not sufficient to stop secularists from maintaining pressure for political reform. Secularist opposition joined in concert with Muslim Brotherhood members in alliances to press for further democratization, despite significant differences in their political preferences (LustOkar 2005). The phenomenon was not limited to the MENA. In Indonesia, where Islamists had also been allowed to mobilize, secularists and Islamists joined forces in 1998. Despite personal suspicion between secularist opposition leaders and the emerging leader of the Muslim opposition, Amien Rais, the student demonstrations in April 1998 showed "extensive collaboration between secular social democrats and Muslim student groups" (Hefner 2000: 200-201). ${ }^{9}$

Importantly, Herb (2005a) argues that opposition groups were also willing to demand reforms when Islamist forces were weak or nearly non-existent. Examining the 12 transitions to democracy in Muslim-majority states prior to 2005 , he finds that in seven of the transitions, Islamist parties were weak or nonexistent. (In the remaining cases, the secularist opposition was stronger than included Islamist parties.) Where Islamist forces are absent, and therefore not included in the formal political sphere, we should also expect that opposition forces would press for reform.

In short, during the Third Wave, when fear of political Islam was high, institutions structuring the relationship between the state, opposition, and political Islam influenced opposition willingness to demand reform, as well as the state's ability to resist such demands. Where the regime based its legitimacy on secularist ideologies, secularist opposition was less likely to press for reforms. They feared that Islamists would hijack the reform process, leading to the establishment of a more conservative, Islamist regime. Similarly, where the regime excluded Islamist forces, secularist opponents were more uncertain regarding the strength and demands of Islamist movements. Once again, they were less likely to demand reform.

Importantly, however, the argument is not a deterministic one. Over time, the arrangements existing in 1980 had less of an impact on subsequent demands for reform, as intervening events lead to change in these institutions in some cases. Where Islamists were then allowed to mobilize, the secularist-Islamist tension was reduced. At the same time, discontent with the status quo can increase to the point where even fear of Islamist take-over is not sufficient to thwart mobilization. These factors help to explain why January 2011 saw the reticence to push for change in the 1990s and early 2000s turn seemingly overnight into a movement that shook the Arab world.

\footnotetext{
${ }^{9}$ See also Weiss (2004).
} 


\section{Variation Explained: Cross-Regional Analysis}

A cross-regional analysis of states with predominantly Muslim societies supports the argument that the institutional arrangements combined with historical experience that highlighted the "Islamist threat" in the MENA affected the extent to which authoritarian leaders responded to demands for political liberalization. The analysis demonstrates that even when other socio-economic factors that may influence liberalization and democratization are taken into account, institutions governing the relationship between Islam and the state had a significant effect on the extent of political reform. The results show that the MENA region is exceptional: allowing Islamist forces to operate openly in the region increases the likelihood of reform in the MENA, but not throughout the Muslim world. This suggests that the experiences of failed secularist-Islamist cooperation in Iran, Syria, Egypt, and then Algeria left a stronger legacy of fear and uncertainty in the MENA than elsewhere. Yet, while the importance of the Islamist threat and the institutional mechanisms that mediate operate somewhat differently in the region, the underlying political dynamics are not "exceptional."

\section{Data}

The analysis examines 42 states with predominantly Muslim populations to determine the extent to which institutional arrangements affects the levels of civil and political liberties. ${ }^{10}$ If the hypotheses set forth above are correct, two factors affected the extent of political reform. The first was the inclusion of Islamist forces in the formal political sphere: opposition was less likely to push for reform when Islamists had been excluded from the political system and therefore were seen as more likely to constitute strong, radical, non-democratic forces. In these cases, societies should have experienced less political reform than where Islamists were not seen as a potential threat. Second is whether the regime uses political Islam was a basis of legitimacy. Where it was, secularist opponents were less likely to believe that a successive regime would be more Islamist than the current one. They were then more likely to press for reforms.

The variables used to test these hypotheses include:

Level of Political Liberalization To test the extent of liberalization, I study the difference in political liberalization between 1980 (the point at which the institutional mechanisms governing the relationship between Islam and the state

\footnotetext{
${ }^{10}$ The full dataset includes 42 cases which the Pew Forum on Religion and Public Life (2011) found to have more than 50\% Muslim societies. These include: Afghanistan, Albania, Algeria, Bahrain, Bangladesh, Brunei, Burkina Faso, Chad, Comoros, Djibouti, Egypt, Gambia, Guinea, Indonesia, Iran, Iraq, Jordan, Kazakhstan, Kuwait, Kyrgyzstan, Libya, Malaysia, Mali, Mauritania, Morocco, Niger, Nigeria, Oman, Pakistan, Qatar, Saudi Arabia, Senegal, Sierra Leone, Somalia, Sudan, Syria, Tajikistan, Tunisia, Turkey, Turkmenistan, UAE, and Uzbekistan.

However, many cases were dropped in some models due to missing data on growth and gender variables: Afghanistan, Djibouti, Iran, Mauritania, Niger, Iraq, Kazakhstan, Kyrgyzstan, Libya, Qatar, Sierra Leone, Somalia, Tajikistan, Turkmenistan, Uzbekistan, and UAE. Lebanon is omitted from the analysis as it was engaged first in civil war and then under Syrian occupation during the period studied here.
} 
are measured) and both one and two decades later (e.g., 1980-1990 and 1980-2000). Considering the extent of liberalization both one and two decades after the baseline measure allows us to examine how initial institutional arrangements affected the degree of liberalization over time.

Arguably, liberalization is a multi-faceted and complex phenomenon, which can take various forms. It includes everything from expanding freedom of association and political expression to establishing institutions that widen access to political decision-making. To establish robustness, three measures are used in these tests: Polity IV, ${ }^{11}$ Polity IV Competitiveness indicator, ${ }^{12}$ and the Vanhanen democracy index. ${ }^{13}$ Polity IV focuses on the presence of autocratic and democratic regime characteristics, the Polity IV Competitiveness scale examines a subset of regime characteristics focused on the degree of political competition, and the Vanhanen democracy index focuses on the participation and the competition in elections. ${ }^{14}$ The mean and the variance of these measures are found in Table 2. These different measurements yield slightly different but consistent results, as seen in Tables 3 and 4 , respectively.

Islamist Inclusion Islamist inclusion is included as a dummy variable, coded 1 if institutional arrangements permitted the participation of independent, politically involved Islamist organizations in 1980, and 0 if not. The year 1980 provides an important baseline. Coming on the heels of the Iranian revolution, it reflects the institutions structuring the relationship between Islam and the state as political Islam became increasingly strong. Moreover, it reflects the institutional arrangements that influenced relationships between secularists, Islamists, and the state as economic and political conditions spurred the Third Wave of democratization in subsequent decades. Finally, while we expect that the institutional arrangements are more significant in the MENA than elsewhere in the Muslim world, 1980 nevertheless provides a good baseline for comparison across the cases as it comes relatively near the beginning of the Third Wave of democratization.

The data was made available by Quinn Mecham, and a word on the coding is in order. To avoid contaminating the analysis, experts independently coded the variables, obtaining at least two codings for each case. In all but one case, that of Senegal, researchers agreed. Thus, regarding Senegal, I ran the analysis with both codings. The results, however, were not significantly different.

Islam as Basis of Regime Again, this was tested with data available from Quinn Mecham, based on expert codings of whether or not Islam was a basis of the regime

\footnotetext{
${ }^{11}$ The "Polity Score" (of the year 2000) captures this regime authority spectrum on a 21-point scale ranging from -10 (hereditary monarchy) to +10 (consolidated democracy). The Polity scheme consists of six component measures that record key qualities of executive recruitment, constraints on executive authority, and political competition.

12 The Polity IV Competitiveness indicator records the key qualities of political competition.

13 The Polyarchy dataset is compiled by Tatu Vanhanen, emeritus professor at the University of Tampere and at the University of Helsinki and covers 187 countries over the period from 1810 to 2000 .

${ }^{14}$ Similar results were also found in analyses using Freedom House measures of civil and political liberties as the dependent variable.
} 
Table 2 Summary statistics of dependent variables

\begin{tabular}{llrrrr}
\hline & Observations & Mean & Std. Dev. & Min. & Max. \\
\hline Vanhanen Democracy Index, Change 1980-1990 & 37 & 4.35 & 20.68 & -66.2 & 63.7 \\
Vanhanen Democracy Index, Change 1980-2000 & 37 & 11.35 & 18.19 & -29 & 70 \\
Polity IV, Change 1980-1990 & 36 & 1.28 & 4.91 & -12 & 15 \\
Polity IV, Change 1980-2000 & 37 & 4.35 & 5.75 & -13 & 14 \\
Polity IV Competitiveness Index, Change 1980-1990 & 35 & 1.14 & 2.59 & -3 & 8 \\
Polity IV Competitiveness Index, Change 1980-2000 & 34 & 2.53 & 3.43 & -8 & 8 \\
\hline
\end{tabular}

in 1980. The dummy variable was coded 1 if it was and 0 if not. There were no disagreements between experts in this coding.

MENA The argument that the historical experiences of the MENA influence the level of liberalization are tested by a dummy variable coded 1 if a country is in the region and 0 if it is not.

Arab The argument that it is an Arab rather than a MENA democracy gap is tested using a dummy variable coded 1 if the country has a majority Arab population and 0 otherwise.

MENA*Islamist Inclusion The analysis included an interaction term denoting when Islamists were included in a MENA country.

Arab*Islamist Inclusion The analysis included an interaction term denoting when Islamists were included in an Arab-majority country. These variables allow us to test whether or not the relationship between Islamist inclusion and reform is similar in Arab and non-Arab regimes.

Economic Control Variables Following long-standing arguments that economic wealth and the presence of oil influence democratization (Crystal 1990; Chaudhry 1997; Beblawi and Luciani 1987; Herb 2005a, b; Lipset 1959; Przeworski et al 2000; Ross 2001; Vandewalle 1998), I included three economic control variables drawn from World Bank data: the average GNI per capita from 1980 to 1990 or from 1980 to 2000, the average GDP growth rate from 1980 to 1990 or from 1980 to 2000 , and mineral wealth as a percentage of GDP.

Social Control Variables I included percentage Muslim to examine the counterargument that it is simply the existence of high percentages of Muslims that thwarts liberalization. Two measures of "female subordination" were included both as control variables and to test recent, interesting hypotheses within the context of only predominantly Muslim states (Fish 2002; Hudson and Den Boer 2002). Data from Steve Fish was used to measure female subordination, ensuring exact replication of these variables. These included the literacy gap in 1990 (male literacy minus female literacy rates) and the sex ratio in 2000 as a ratio of males to females. 
Table 3 Changes in political competition, 1980-1990

\begin{tabular}{|c|c|c|c|}
\hline & Polity IV & Polity IV Political Competition & Vanhanen Democracy Index \\
\hline Deliberalized Regimes & $\begin{array}{l}\text { Bangladesh } \\
\text { Chad } \\
\text { Nigeria }\end{array}$ & $\begin{array}{l}\text { Bangladesh } \\
\text { Nigeria }\end{array}$ & $\begin{array}{l}\text { Bangladesh } \\
\text { Iran } \\
\text { Nigeria } \\
\text { Sudan } \\
\text { Syria }\end{array}$ \\
\hline Stagnant Regimes & $\begin{array}{l}\text { Bahrain } \\
\text { Burkina Faso } \\
\text { Djibouti } \\
\text { Egypt } \\
\text { Gambia } \\
\text { Indonesia } \\
\text { Iraq } \\
\text { Libya } \\
\text { Malaysia } \\
\text { Mali } \\
\text { Mauritania } \\
\text { Morocco } \\
\text { Niger } \\
\text { Oman } \\
\text { Qatar } \\
\text { Saudi Arabia } \\
\text { Sierra Leone } \\
\text { Somalia } \\
\text { Sudan } \\
\text { Syria }\end{array}$ & $\begin{array}{l}\text { Bahrain } \\
\text { Burkina Faso } \\
\text { Djibouti } \\
\text { Egypt } \\
\text { Gambia } \\
\text { Guinea } \\
\text { Indonesia } \\
\text { Iraq } \\
\text { Libya } \\
\text { Malaysia } \\
\text { Mali } \\
\text { Mauritania } \\
\text { Morocco } \\
\text { Niger } \\
\text { Oman } \\
\text { Qatar } \\
\text { Saudi Arabia } \\
\text { Sierra Leone } \\
\text { Somalia } \\
\text { Sudan } \\
\text { Syria } \\
\text { UAE }\end{array}$ & $\begin{array}{l}\text { Afghanistan } \\
\text { Albania } \\
\text { Bahrain } \\
\text { Brunei } \\
\text { Burkina Faso } \\
\text { Chad } \\
\text { Djibouti } \\
\text { Guinea } \\
\text { Indonesia } \\
\text { Iraq } \\
\text { Kuwait } \\
\text { Libya } \\
\text { Mali } \\
\text { Oman } \\
\text { Qatar } \\
\text { Saudi Arabia } \\
\text { Turkmenistan } \\
\text { UAE }\end{array}$ \\
\hline Liberalized Regimes & $\begin{array}{l}\text { Albania } \\
\text { Algeria } \\
\text { Comoros } \\
\text { Guinea } \\
\text { Jordan } \\
\text { Pakistan } \\
\text { Senegal } \\
\text { Tunisia } \\
\text { Turkey } \\
\text { Turkmenistan } \\
\text { UAE } \\
\text { Uzbekistan }\end{array}$ & $\begin{array}{l}\text { Albania } \\
\text { Algeria } \\
\text { Comoros } \\
\text { Jordan } \\
\text { Pakistan } \\
\text { Senegal } \\
\text { Tunisia } \\
\text { Turkey }\end{array}$ & $\begin{array}{l}\text { Algeria } \\
\text { Comoros } \\
\text { Egypt } \\
\text { Gambia } \\
\text { Jordan } \\
\text { Malaysia } \\
\text { Morocco } \\
\text { Pakistan } \\
\text { Senegal } \\
\text { Sierra Leone } \\
\text { Somalia } \\
\text { Tunisia } \\
\text { Turkey }\end{array}$ \\
\hline
\end{tabular}

Deliberalized regimes are defined as those with a negative difference between the Polity IV, Polity IV Political Competition, and Vanhanen Democracy Index scores in 1990 and 1980. Stagnant regimes are defined as those with a zero difference between the Polity IV, Polity IV Political Competition, and Vanhanen Democracy Index scores in 1990 and 1980. Liberalized regimes are defined as those with a positive difference between the Polity IV, Polity IV Political Competition, and Vanhanen Democracy Index scores in 1990 and 1980 
Table 4 Changes in political competition, 1980-2000

\begin{tabular}{|c|c|c|c|}
\hline & Polity IV & $\begin{array}{l}\text { Polity IV } \\
\text { Political competition }\end{array}$ & Vanhanen democracy index \\
\hline Deliberalized Regimes & $\begin{array}{l}\text { Chad } \\
\text { Gambia } \\
\text { Malaysia } \\
\text { Nigeria }\end{array}$ & $\begin{array}{l}\text { Gambia } \\
\text { Nigeria }\end{array}$ & $\begin{array}{l}\text { Iran } \\
\text { Nigeria }\end{array}$ \\
\hline Stagnant Regimes & $\begin{array}{l}\text { Egypt } \\
\text { Indonesia } \\
\text { Iraq } \\
\text { Jordan } \\
\text { Libya } \\
\text { Qatar } \\
\text { Saudi Arabia } \\
\text { Sudan } \\
\text { UAE }\end{array}$ & $\begin{array}{l}\text { Bahrain } \\
\text { Egypt } \\
\text { Indonesia } \\
\text { Iraq } \\
\text { Jordan } \\
\text { Libya } \\
\text { Malaysia } \\
\text { Oman } \\
\text { Qatar } \\
\text { Saudi Arabia } \\
\text { Sudan } \\
\text { Syria } \\
\text { UAE }\end{array}$ & $\begin{array}{l}\text { Afghanistan } \\
\text { Bahrain } \\
\text { Brunei } \\
\text { Comoros } \\
\text { Indonesia } \\
\text { Iraq } \\
\text { Jordan } \\
\text { Libya } \\
\text { Oman } \\
\text { Pakistan } \\
\text { Qatar } \\
\text { Saudi Arabia } \\
\text { Sierra Leone } \\
\text { Somalia } \\
\text { UAE }\end{array}$ \\
\hline Liberalized Regimes & $\begin{array}{l}\text { Albania } \\
\text { Algeria } \\
\text { Bahrain } \\
\text { Bangladesh } \\
\text { Comoros } \\
\text { Djibouti } \\
\text { Guinea } \\
\text { Kuwait } \\
\text { Mauritania } \\
\text { Morocco } \\
\text { Niger } \\
\text { Oman } \\
\text { Pakistan } \\
\text { Senegal } \\
\text { Sierra Leone } \\
\text { Somalia } \\
\text { Syria } \\
\text { Tunisia } \\
\text { Turkey }\end{array}$ & $\begin{array}{l}\text { Albania } \\
\text { Algeria } \\
\text { Bangladesh } \\
\text { Comoros } \\
\text { Djibouti } \\
\text { Guinea } \\
\text { Kuwait } \\
\text { Mauritania } \\
\text { Morocco } \\
\text { Niger } \\
\text { Pakistan } \\
\text { Senegal } \\
\text { Tunisia } \\
\text { Turkey }\end{array}$ & $\begin{array}{l}\text { Albania } \\
\text { Algeria } \\
\text { Bangladesh } \\
\text { Chad } \\
\text { Djibouti } \\
\text { Egypt } \\
\text { Gambia } \\
\text { Guinea } \\
\text { Kuwait } \\
\text { Malaysia } \\
\text { Morocco } \\
\text { Senegal } \\
\text { Sudan } \\
\text { Syria } \\
\text { Tunisia } \\
\text { Turkey }\end{array}$ \\
\hline
\end{tabular}

Deliberalized regimes are defined as those with a negative difference between the Polity IV, Polity IV Political Competition, and Vanhanen Democracy Index scores in 2000 and 1980. Stagnant regimes are defined as those with a zero difference between the Polity IV, Polity IV Political Competition, and Vanhanen Democracy Index scores in 2000 and 1980. Liberalized regimes are defined as those with a positive difference between the Polity IV, Polity IV Political Competition, and Vanhanen Democracy Index scores in 2000 and 1980 
Political Control Variables I tested a series of political variables to ensure that they did not drive the results. These included the years since independence and the age of the current regime in 1990, and Barbara Geddes (2000) regime type variables, extended to include missing cases and monarchies. This was particularly important since, as argued previously, different regime types may foster different approaches toward the opposition.

\section{Results}

The results demonstrated strong and stable support for the two main hypotheses, particularly given the small number of cases. Institutions governing the relationship between Islam, the state, and the opposition in 1980 are significantly associated with the degree of political reform in 1990, although by 2000 their strength diminishes such that they are no longer significant in the full model specification. This effect is particularly strong in the MENA. Importantly, these institutional influences are far more closely related to the degree of reform than alternative competing explanations: regime type, oil, economic growth and development, and gender relations.

The results are exhibited in Tables 5 and 6. Economic control variables were not significantly associated with reform in all but one model specification. Mineral wealth was also not significant in any of the fully specified models.

Social control variables were generally not significant. The percentage of Muslim was never substantively or statistically significant, and as it was never part of the theoretical model specification, it is dropped from the results presented here. The variables for female subordination did not show strong support for this line of argumentation, at least with regard to the extent of political liberalization in both 1990 and 2000. The literacy ratio was tested as an alternative variable for female subordination, but it was not significant. Only sex ratio is reported in Tables 5 and 6 .

The political control variables - those of the years since independence and the age of the current regime in 1990-consistently had insignificant effects, both substantively and statistically. ${ }^{15}$ Thus, they too were omitted since they were not theoretically driven. Similarly, while monarchy was significantly and negatively associated with the likelihood of liberalization, other regime type variables were insignificant. This is comforting, since it demonstrates that even if there is reason to believe regime type may influence the strategies that state elites take toward the Islamists in the 1980s, it did not determine extent of liberalization which followed.

The extent to which Islam was a basis of the regime in 1980 was significantly related to the extent of reform by 1990. This is consistent with Herb's (2005a) argument, that where Islam is incorporated into the regime, the fear of a post-reform regime being more conservative is muted. Opposition forces are thus more likely to push harder to gain political liberties.

\footnotetext{
15 This remained to be the case in alternative models with only some of the political variables included. The variables of interest also showed remarkable robustness across a wide variety of partial models.
} 
Table 5 Regression analysis on difference in political liberalization, 1980-1990

\begin{tabular}{llll}
\hline Independent Variables & Polity IV & $\begin{array}{l}\text { Polity IV Political } \\
\text { Competition }\end{array}$ & $\begin{array}{l}\text { Vanhanen Democracy } \\
\text { Index }\end{array}$ \\
\hline Monarchy & $-14.92 * * *(4.18)$ & $-5.97 * *(2.51)$ & $-60.52 * * *(16.37)$ \\
Islam as basis for regime & $10.30^{* * *}(2.93)$ & $4.12 * *(1.74)$ & $47.05 * * *(11.29)$ \\
Islamist inclusion & $-6.10^{* *}(2.65)$ & $-2.11(1.68)$ & $-27.36^{* *}(10.24)$ \\
MENA & $-.12(3.01)$ & $.69(1.79)$ & $-4.22(12.37)$ \\
MENA*Islamist inclusion & $14.33 * * *(4.68)$ & $7.24 * *(2.88)$ & $59.44 * *(16.17)$ \\
Minerals & $-.04(.04)$ & $-.01(.03)$ & $-.25(.18)$ \\
Economic development & $1.72(1.93)$ & $.83(1.15)$ & $5.48(12.66)$ \\
Economic growth & $.73(.48)$ & $.10(.28)$ & $5.16 * *(1.87)$ \\
Sex ratio & $.05(.18)$ & $-.06(.10)$ & $.14(.66)$ \\
Constant & $-9.56(17.03)$ & $4.64(10.19)$ & $-34.83(58.64)$ \\
$R^{2}$ & .62 & .53 & .71 \\
$N$ & 27 & 26 & 26 \\
\hline
\end{tabular}

Entries are coefficient estimates with White-corrected robust standard errors in parentheses $* p<.10 ; * * p<.05 ; * * * p<.01$

The impact of Islamic inclusion and MENA on the extent of reform in 1990, in particular, was also strong and significant. Similar results were obtained using the measurements for Arab and Islamic inclusion as well, although due to space considerations this alternative specification is not reported in Tables 5 and 6 . In both cases, the inclusion of Islamist forces in the Arab world or the region was associated

Table 6 Regression analysis on difference in political liberalization, 1980-2000

\begin{tabular}{llll}
\hline Independent Variables & Polity IV & $\begin{array}{l}\text { Polity IV Political } \\
\text { Competition }\end{array}$ & $\begin{array}{l}\text { Vanhanen Democracy } \\
\text { Index }\end{array}$ \\
\hline Monarchy & $.15(6.5)$ & $-.55(3.81)$ & $-12.29(18.38)$ \\
Islam as a basis for regime & $-1.56(4.45)$ & $1.06(2.63)$ & $-2.12(12.62)$ \\
Islamist inclusion & $.22(4.22)$ & $1.06(2.62)$ & $-1.93(12.00)$ \\
MENA & $-1.04(4.6)$ & $-.14(2.65)$ & $5.10(13.35)$ \\
MENA*Islamist inclusion & $5.32(6.3)$ & $-2.17(3.77)$ & $30.16(17.81)$ \\
Minerals & $-.03(.07)$ & $-.03(.04)$ & $-.16(.20)$ \\
Economic development & $3.02(5.02)$ & $2.86(3.3)$ & $13.20(14.43)$ \\
Economic growth & $-1.01(1.06)$ & $-.78(.61)$ & $-2.41(3.09)$ \\
Sex ratio & $-.26(.25)$ & $-.27(.16)$ & $-.81(.71)$ \\
Constant & $26.96(21.54)$ & $24.65(12.60)$ & $68.35(60.98)$ \\
$R^{2}$ & .24 & .33 & .44 \\
$N$ & 28 & 26 & 26 \\
\hline
\end{tabular}

Entries are coefficient estimates with White-corrected robust standard errors in parentheses $* p<.10 ; * * p<.05 ; * * * p<.01$ 
with greater reform. Outside the Arab world and the MENA region, however, the inclusion of Islamist forces was associated with less reform.

What do these results tell us? In the MENA, historical experiences and institutional structures combined to heighten the fear of political Islam. In these cases, political reform was more limited than it was where Islamist forces had been formally included in the political sphere. The results demonstrate that the institutional exclusion and historical experiences in the MENA were important in determining why the region, generally, saw less political liberalization than other predominantly Muslim societies, and explains the variation within the region. Where Islamists were included in the MENA, states were no less likely to be liberal than cases outside the region. This would not have been the expected result if, for instance, the strategic importance of the region or "Arab culture" was responsible for the resistance to liberalization. At the same time, the analysis clearly shows that historical experiences matter. Where these experiences were absent, the inclusion or exclusion of Islamists in the 1980s was much less important in determining the level of political and civil liberties that were achieved.

\section{Prospects for Democracy: Then and Now}

The failure of MENA states to democratize during the Third Wave did lie, in part, in the existence of Islam, but in very different ways than has often been suggested. It was not the inability of Muslims to embrace democracy that led to stalled liberalization; rather, the historical experiences of the region in the 1970s created a legacy of fear through which incumbents could divide their opponents. These experiences resonated more strongly within the MENA than they did in other regions. They also had greater impact where institutional barriers existed that blocked interactions between Islamic and secular oppositions. Thus, even as pressures for democratization mounted, and indeed even after the steps toward liberalization were announced, incumbents could drive a wedge between Islamic and secularist opposition groups, weakening these forces in their struggle against the regime.

That historical experiences mattered is perhaps best illustrated by the regions in which these were absent, or at least resonated less. Outside the MENA, Islamist inclusion in the 1980s was much less important in determining the level of political and civil liberties that were achieved later. Democratization did not proceed unencumbered in Asia and Africa, but it was at least facilitated by the relative lack of fear between Islamist and secularist forces. In Asia, where regimes had claimed Islam as a basis of the regime, political Islam was neither an unknown force nor the only viable opposition to the incumbent regime. Consequently, for example, in Bangladesh after the fall of Ershad, the Islamist party did in fact worse than the secular opposition. In Asia, similarly, radical political Islam had not become a major force. Thus, although Islamist and secularist parties both competed in the Senegalese elections, Islamist forces were not considered a threat. Islamists were well-known forces with the same political disadvantages and blemished records as their secularist counterparts. The regime could not use the threat of Islamists to drive a wedge between its opponents, and the opposition pressed for continued political change. 
In the MENA, state elites fostered the fear of Islamists that derived from the legacies of Egypt, Iran, Syria, and Algeria, using it not only to fracture potential coalitions between Islamists and secularists, but also to splinter both sides of the opposition. The extent to which they could use this fear to suppress pressure for change depended on the institutions structuring the relationships between Islam, opposition, and the state. Where Islam was a basis for the regime, the fear of Islamists was weaker and the pressure for change increased. Even more importantly, where Islamists were included in the MENA, states were as likely to liberalize as regimes outside the region. This would not have been the expected result if, for instance, the strategic importance of the region or "Arab culture" was responsible for the resistance to liberalization.

The fact that Islamist inclusion was more important within the MENA than outside it suggests that historical lessons are more clearly learned within regions than outside of them. African and Asian elites were less aware of the experiences in Egypt, Iran, and Syria during the 1970s than elites in the MENA. However, elites see experiences in similar states as potentially more likely to be repeated within their own. Citizens within the same region also identify with each other more than they do with those in other regions, and thus, during the Third Wave, the fear resonated more strongly with them than it did in Africa or elsewhere in Asia.

That diffusion is more powerful within regions than across them is important both theoretically and empirically. Neither prerequisites nor contingency theories of democratization have incorporated fully the importance of such diffusion of ideas across states, or the impact of such lessons on the abilities of various actors to demand reform. Moreover, it also helps explain why the Jasmine Revolution of January 2011 that forced Tunisian President Ben Ali from power reverberated so rapidly across the Arab world. Looking to Arabs as a symbol of what is possible, Egyptians, Yemenis, Libyans, and others suddenly believed that they could push long-standing, repressive leaders from power.

The analysis here also helps explain why the willingness to challenge regimes that had been limited during the Third Wave suddenly emerged full-force in 2011. The Jasmine Revolution surprised the world, but the prospects for greater pressure for reform had been growing. The past decades had seen growing inclusion of the Islamist forces in states such as Morocco and Egypt, which fostered communication between Islamists and secularists. Relationships were sometimes rocky and fraught with setbacks, but the fear and the uncertainty of Islamists reduced and the opportunities for cooperation increased.

Indeed, the January 25th Egyptian revolution appears to have derived directly from cooperation between Muslim Brothers and secularist opponents to boycott the second round of the 2010 Parliamentary elections, and subsequent communications. As one Egyptian secularist argued, "We just got to know, trust and like each other, even-believe it or not-the Brothers" ("The Muslim Brothers," 2011). Growing communication between these parties allowed them to join in concert to press for greater democratization.

Furthermore, the belief that Islamists - and particularly, radical Islamists - are strong enough to hijack democratization had also declined in the last decades. For some time, scholars have written obituaries of radical Islamist movements (Kepel 2002), and increasingly, other observers have drawn similar conclusions (Gardner 2008; 
Muravchik 2009; Thorne 2009; Zakaria 2010). Some began to argue that the fear of Islamists that had paralyzed pro-democratic forces was driven partly by regimes that held them up as a bogeyman, both as a threat to secularists at home and democracypromoters abroad. Intellectuals like Egyptian Saad Edin Ibrahim began to argue that Islamist parties "should neither be pathologically feared nor cavalierly excluded. Rather, they should be actively engaged and encouraged to evolve into Muslim democratic parties akin to the Christian Democrats in Europe" (Ibrahim 2009).

This new context greatly reduced ruling elites' ability to use the threat of Islamism and promises of gradual reform to maintain power. Decades after elections were called and reforms promised, Arabs across the region saw "democratic practices" corrupted, their rights restricted, and the talk of reform to be empty. Both citizens and elites routinely echoed the sentiments of one taxi driver, who argued, "For 20 years the regime talked of reforms, for another twenty they will talk. But they will never change." 16 Frustrated with increasingly worse conditions, cynical toward promises of reform, and no longer afraid of Islamists, opposition united to demand wholesale change.

Acknowledgment The author gratefully acknowledges Susan Hyde, Amaney Jamal, Stathis Kalyvas, Pierre Landry, Pauline Jones Luong, Nikolay Marinov, Stephen Ndegwa, Marsha Pripstein Posusney, Jessica Weiss, anonymous reviewers, and the editors of Studies in Comparative International Development, as well as the participants in workshops at Duke University, the Mediterranean Social and Political Research Meeting, Stanford University, the University of Notre Dame, Wesleyan University, and Yale University for their extremely helpful comments on earlier drafts, and Brian Kelly for the excellent research assistance.

Open Access This article is distributed under the terms of the Creative Commons Attribution Noncommercial License which permits any noncommercial use, distribution, and reproduction in any medium, provided the original author(s) and source are credited.

\section{References}

Abdalla A. Egypt's Islamists and the State: from complicity to confrontation. Middle East Report. 1993; (July-August): 28-31.

Acemoglu D, Robinson JA. Economic origins of dictatorship and democracy. New York: Cambridge University Press; 2006.

Al-Ahram. Charting untrodden ground. Al-Ahram Weekly 201 (29 December - 4 January). 1994-5; weekly.ahram.org.eg/archives/1994poll.yesss.htm..

Albrecht H, editor. Contentious politics in the Middle East. Gainesville: University Press of Florida; 2010.

Ayubi NNM. The political revival of Islam; the case of Egypt. IJMES. 1980;12:481-99.

Ayubi N. Political Islam: religion and politics in the Arab World. London: Routledge; 1991.

Beblawi Hazem and Giacomo Luciani. The Rentier state: nation, state and integration in the Arab World, vol 2. New York: Croom Helm; 1987.

Bellin E. Stalled democracy: capital, labor, and the paradox of state-sponsored development. Ithaca: Cornell University Press; 2002.

Bellin Eva. The robustness of authoritarianism in the Middle East: a comparative perspective. Comparative Politics. 2004;36(2):139-57.

Bermeo Nancy. Civil society after democracy. In: Bormeo Nancy, Philip Nord, editors. Civil society before democracy. New York: Rowman and Littlefield Publishers, Inc.; 2000.

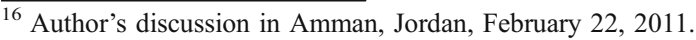


Boix C, Stokes S. Endogenous democratization. World Politics. 2003;55(4):517-49.

Brownlee J. Authoritarianism in an age of democratization. Cambridge: Cambridge University Press; 2007.

Brumberg Daniel. Middle East studies after 9/11. Journal of Democracy. 2002;13(3):109-16.

Brumberg D, Diamond L. Introduction. In: Larry Diamond, Marc Plattner, Daniel Brumberg, editors. Islam and democracy in the Middle East. Baltimore: Johns Hopkins University Press; 2003. p. xiii.

Chaudhry K. The price of wealth. Ithaca: Cornell University Press; 1997.

Crystal J. Oil and politics in the Gulf. Cambridge: Cambridge University Press; 1990.

Djerejian EP. United States policy toward Islam and the arc of crisis. Baker Institute Study. 1995;1.

Fish MS. Islam and authoritarianism. World Politics. 2002;55:4-37.

Gandhi Jennifer, Przeworski Adam. Cooperation, cooptation, and rebellion under dictatorships. Economics \& Politics. 2006;18(1):1-26.

Gardner F. Al-Qaeda faces Islamist backlash. British Broadcasting Company. 2008. 7 August. Accessed at http://news.bbc.co.uk/2/hi/south_asia/7546322.stm in February 2011.

Geddes B. The Breakdown of Authoritarian Regimes: Empirical Tests and Game Theoretic Arguments. Paper presented at the Center for Comparative Research. Yale University; 2000.

Hadenius Axel, Jan Teorell. Pathways from authoritarianism. Journal of Democracy. 2007;18(1):145-53.

Haggard S, Kaufman R. The political economy of democratic transitions. Princeton: Princeton University Press; 1995.

Hamladj N. Do political dynamics travel? Political liberalization in the Arab World. EUI Working Paper. 2002.

Hefner R. Civil Islam: Muslims and democratization in Indonesia. Princeton: Princeton University Press; 2000.

Herb M. All in the family. Albany: SUNY Press; 1999.

Herb M. No representation without taxation? Rents, development and democracy. Comparative Politics. 2005a;37(3):297-316.

Herb, M (2005) Islamist movements and the problem of democracy in the Arab World. Paper presented at the American Political Science Association Annual Meeting. September 1-4.

Hudson Valerie, Den Boer Andrea. A surplus of men, a deficit of peace: security and sex ratios in Asia's largest states. International Security. 2002;26(4):5-38.

Huntington Samuel. Will more countries become democratic? Political Science Quarterly. 1984;99 (2):193-218.

Ibrahim SE. Egypt's Islamic activism in the 1980s. Third World Quarterly. 1988;10(2):632-57.

Ibrahim SE. Egypt's Islamic Militants. MERIP Reports. 1982; (February): 5-14.

Ibrahim SE. The Mideast's new spring of freedom. Wall Street Journal. 2009. June 24.

Islamic Unity and Political Change: Interview with Shaykh Muhammed Hussayn Fadlallah. 1995. Journal of Palestine Studies 25(1) (Autumn): 61-75.

Jamal A. Barriers to democracy: the other side of social capital in Palestine and the Arab World. Princeton: Princeton University Press; 2007.

Jamal A. Democratic citizens in non-democratic nations: civic participation and associational life in the West Bank. Ph.D. Dissertation. University of Michigan; 2002.

Jamal Amaney, Tessler Mark. Attitudes in the Arab World. Journal of Democracy. 2008;19(1):97-110.

Kalyvas S. Commitment Problems in Emerging Democracies: The Case of Religious Parties. Comparative Politics. 2000;32(4):379-399.

Karawan Ibrahim. Political parties between state power and Islamist opposition. In: Charles Butterworth, Zartman I William, editors. Between Islam and the state. Cambridge: Cambridge University Press; 2001. p. $158-83$.

Kepel G. Jihad: the trail of political Islam. Cambridge: Harvard University Press; 2002. Trans. Anthony Roberts.

Kostiner J, Teitelbaum J. State-formation and the Saudi monarchy. In: Kostiner J, editor. Middle East monarchies: the challenge of modernity. Boulder, CO and London: Lynne Rienner; 2000.

Kotob SA. The accommodationists speak: goals and strategies of the Muslim brotherhood of Egypt. IJMES. 1995;27(3):321-39.

Levi Margaret. Thinking about how democracy works. Politics and Society. 1996;24(1):7. 19, 45.

Linz J. Transitions to Democracy. Washington Monthly (Summer). 1990.

Linz J, Stepan A. Problems of democratic transition and consolidation: Southern Europe, South America, and post-communist Europe. Baltimore: The John Hopkins University Press; 1996.

Lipset S Martin. Some social requisites of democracy: economic development and political legitimacy. American Political Science Review. 1959;53(1):69-105.

Lust-Okar E. Structuring conflict in the Arab World. Cambridge: Cambridge University Press; 2005.

Lust-Okar E. Divided they rule: The management and manipulation of political opposition. Comparative Politics. 2004; (January): 159-179. 
Lust-Okar E. National and subnational identities: state policies and implications in the context of regional instability. Quaderni di Relazioni Internazionali. 2007. September.

Lust-Okar E, Zerhouni S, editors. Political participation in the Middle East. Boulder: Lynne Reinner Press; 2008.

McAdam D, McCarthy JD, Zald MN, editors. Comparative perspectives on social movements opportunities, mobilizing structures, and framing. Cambridge, UK: Cambridge University Press; 1996.

Muravchik J. Radical Islam in decline. Ikhwanweb 4 July 2009. Accessed at http://www.ikhwanweb.com/ article.php?id=20692 in February 2011.

Murphy EC. Institutions, Islam and democracy promotion: explaining the resilience of the authoritarian state. Mediterranean Politics. 2008;13(3):459-66.

Norton, A.R. Civil society in the Middle East, Vols. 1 and 2. New York: EJ Brill; 1995 and 1996.

O'Donnell G, Schmitter PC, Whitehead L, editors. Transitions from authoritarian rule. Baltimore: Johns Hopkins University Press; 1987.

Ottaway M, Choucair-Vizoso J, editors. Beyond the façade: political reform in the Arab World. Washington: Carnegie Endowment for International Peace; 2008.

Pripstein Posusney M. The Middle East's democracy deficit in comparative perspective. In: Pripstein Posusney M, Angrist MP, editors. Authoritarianism in the Middle East: regimes and resistance. Boulder: Lynne Reinner Publishers; 2005.

Przeworski A, Alvarez M, Cheibub J, Limongi F. Democracy and development: political institutions and material well-being in the world. Cambridge: Cambridge University Press; 2000.

Pew Forum on Religion and Public Life (2011) The future of the global Muslim population. http:// pewforum.org/The-Future-of-the-Global-Muslim-Population.aspx

Remmer K. New theoretical perspectives on democratization. Comparative Politics. 1995;28(1):103-22.

Ross Michael. Does oil hinder democracy? World Politics. 2001;53(3):325-61.

Schlumberger O, editor. Debating Arab authoritairanism: dynamics and durability in nondemocratic regimes. Stanford: Stanford University Press; 2007.

Schwedler J. Framing Political Islam in Jordan and Yemen. New York University. Ph.D. Dissertation. 2000.

Stepan A, Robertson G. An "Arab" more than a "Muslim" democracy gap. Journal of Democracy. 2003;14(3):30-44.

Stone M. The agony of Algeria. New York: Columbia University Press; 1997.

Tarrow S. Power in movement: social movements and contentious politics. 2nd ed. Cambridge: Cambridge University Press; 1998.

Tarrow S. Making social science work across space and time: a critical reflection on Robert Putnam's Making Democracy Work. APSR. 1996;90:389-97.

Tessler M. Do Islamic orientations influence attitudes toward democracy in the Arab World? Evidence from Egypt, Jordan, Morocco, and Algeria. Int J Comp Sociol. 2002;43(3):229-49.

Tessler M. Religion, religiosity and the place of Islam in political life: insights from the Arab barometer surveys. MELG. 2010;2:221-52.

The Muslim Brothers. Wall Street Journal, February 16;2011:15

Thorne J. Islamists sixth in Moroccan vote. The National, 14 June 2009. Accessed at http://www. thenational.ae/news/worldwide/africa/islamists-sixth-in-moroccan-vote.

Vandewalle D. Libya since independence: oil and state-building. Ithaca: Cornell University Press; 1998.

Voll John. Sultans, saints and presidents: the Islamic community and States in North Africa. In: Entelis JP, editor. Islam, democracy and the state in North Africa. Bloomington: Indiana University Press; 1997. p. 1-16.

Volpi F. Islam and democracy: the failure of dialogue in Algeria. London: Pluto; 2003.

Weiss M. The changing shape of Islamic politics in Malaysia. J East Asian Stud. 2004;4:129-73.

Wiktorowicz Quintan. Islamic activism. A social movement theory approach. Bloomington: Indiana University Press; 2004.

Zakaria F. How moderate Muslim leaders waged war on extremists — and won. Newsweek 12 February 2010. Accessed at http://www.newsweek.com/2010/02/11/the-jihad-against-the-jihadis.html in February 2011.

Ellen Lust is Associate Professor of Political Science, Yale University. 